\title{
A comprehensive comparison between cementless and cemented fixation in the total knee arthroplasty: an updated systematic review and meta-analysis
}

Yuan Liu', Yi Zeng ${ }^{2,1}$, Yuangang $\mathrm{Wu}^{1}$, Mingyang $\mathrm{Li}^{1}$, Huiqi Xie ${ }^{1}$ and Bin Shen ${ }^{1 *}$ (D)

\begin{abstract}
Background: Whether the cement should be used in the total knee arthroplasty (TKA) was still in controversy. This meta-analysis was performed to compare the efficacy of two kinds of fixation.

Methods: Randomized controlled trials (RCTs), prospective/retrospective observational studies from PubMed (on 2019 September), EMBASE (on 2019 September), and the Cochrane Central Register of Controlled Trials (CENTRAL) and Web of Science (on 2019 September) were searched. Only studies followed more than 2 years was included for the review. The PRISMA guidelines and Cochrane Handbook were adopted to assess the quality of the results reported in included studies to ensure that the results of our meta-analysis were reliable and veritable. The continuous and dichotomous outcomes were collected in a standard form, and the data were analyzed by Review Manager 5.3 software. Finally, the results were presented in the Forest plots.

Results: Twenty-six studies involving 2369 patients in cementless TKA and 2654 patients in cemented TKA were included. The rate of revision was not significantly different in two groups $(p=0.55)$. More than eight reasons caused revision were found in our study, the aseptic loosing was the most common, followed by the periprosthetic joint infection (PJI), neither was significantly different ( $p=0.88$ and 0.45 , respectively). While significantly better long-term functional recovery was found in cementless TKA in terms of Knee Society Function Score $(p=0.004)$ and manipulation under anesthesia $(p=0.007)$.

Conclusion: Cementless fixation did not decrease the rate of revision after the total knee arthroplasty compared with the cemented fixation, while the long-term functional recovery was significantly better in the cementless group.
\end{abstract}

Keywords: Total knee arthroplasty, Cement, Cementless, Systematical review, Meta-analysis

\footnotetext{
* Correspondence: shenbin_1971@163.com

'Department of Orthopaedic Surgery, West China Hospital, West China Medical School, Sichuan University, 37\# Guoxue Road, Chengdu 610041, People's Republic of China

Full list of author information is available at the end of the article
}

(c) The Author(s). 2021 Open Access This article is licensed under a Creative Commons Attribution 4.0 International License, which permits use, sharing, adaptation, distribution and reproduction in any medium or format, as long as you give appropriate credit to the original author(s) and the source, provide a link to the Creative Commons licence, and indicate if changes were made. The images or other third party material in this article are included in the article's Creative Commons. licence, unless indicated otherwise in a credit line to the material. If material is not included in the article's Creative Commons licence and your intended use is not permitted by statutory regulation or exceeds the permitted use, you will need to obtain permission directly from the copyright holder. To view a copy of this licence, visit http://creativecommons.org/licenses/by/4.0/ The Creative Commons Public Domain Dedication waiver (http://creativecommons.org/publicdomain/zero/1.0/) applies to the data made available in this article, unless otherwise stated in a credit line to the data. 


\section{Background}

As the gold standard of fixation method in total knee arthroplasty (TKA), cemented fixation occupied 93.5\% in 2010 [1]. There were a series of advantages in conventional cemented fixation in TKA. Firstly, the cemented fixation allows for small bone cut defects, which required less technical challenge compared with the uncemented fixation [2]. Secondly, the cemented fixation could deliver antibiotics into the joint to prevent infection [3]. Thirdly, as an effective barrier, cement could insulate the polyethylene debris from the articular surface and prevent the osteolysis [4]. Therefore, because of the abundant clinical experience and great clinical results, cemented fixation was still most used in TKA. An analysis using New Zealand Joint Registry (NZJR) data revealed that most (91.5\%) of primary TKA were fully cemented with $4.8 \%$ hybrid and $3.7 \%$ uncemented in 96,519 primary TKAs from 1998 to 2017 [5].

However, accompanied with the increasing demand of TKA, the patients underwent TKA are becoming younger and younger [6]. It was predicted that more than half of patients underwent TKA was contributed by patients younger than 65 years old by 2030 [6]. This posed a difficulty to the development of TKA, for the more active lifestyle was needed by younger patients. Therefore, the concern of bone resorption in the bone-cement interface would make the dominance of cemented fixation challenging [7]. Although the preliminary results of cementless fixation was proved discouraging, cementless TKA in young patients was found to have comparable midterm results to cemented TKA [8]. With a biologic bone-implant interface, cementless fixation was determined to prevent the osteolysis and decrease the risk of aseptic loosening, especially in young patients. In addition, with the development of prosthesis design and material renovation, cementless TKA has been introduced to extend the life of prosthesis [9].

Therefore, this study was performed to compare the rate of revision, reasons of revision, functional recovery, and rate of complications in two kinds of fixation in TKA. We hypothesized that the cementless fixation was not inferior to the cemented fixation in terms of rate of revision and functional recovery.

\section{Methods}

The guidelines listed in the Preferred Reporting Items for Systematic Reviews and Meta-Analyses (PRISMA) was the basis of this systematic review and meta-analysis (The PRISMA checklist was shown in the Supplementary Material) [10].

\section{Search strategy}

MEDLINE (1950 to date), PubMed (1966 to date), EMBASE (1974 to date), the Cochrane Central Register of Controlled Trials, the Wanfang database (1982 to date), and the Web of Science were systematically searched for studies on cementless fixation in total knee arthroplasty on 30 August 2019. "Knee, knee replacement, knee arthroplasty, total knee replacement, TKR, total knee arthroplasty, TKA," and "cementless, cemented, uncemented" were used as key words in connection with AND or OR. Meta-analyses were identified by the third reviewer. Then, the references of these metaanalyses were screened to find additional relevant studies. Another reviewer tried to contact expert informants by email to search for unpublished studies. Finally, two reviewers independently assessed the studies, and any discrepancies were resolved by a discussion with the other reviewers.

\section{Inclusion and exclusion criteria}

Studies were included according to the PICOS criteria: (1) population: patients experiencing TKA who were demographically alike; (2) intervention and control: cementless and cemented fixation in TKA; (3) outcomes: patients followed at least 2 years, and rate of revision, reasons of revision, functional recovery, and rate of complication were reported; (4) study design: randomized controlled trial (RCT), prospective, or retrospective observational studies.

Studies were excluded if (1) relevant outcomes were missing or (2) the quality assessment was low (RCT $<5$, non-RCTs < 20) $[11,12]$. (3) The groups in study were not fully cementless and fully cemented that the hybrid fixation was not included in this study.

\section{Quality assessment}

A modified seven-point JADAD scale was adopted to assess the methodological quality of the RCTs [11]. The scale considers five items, namely, randomization, concealment of allocation, double blinding, withdrawals, and dropouts [11]. Based on the Cochrane Handbook, two reviewers independently evaluated the quality of the included RCTs. There was no disagreement between the two reviewers' ratings.

Two reviewers evaluated the quality of non-RCTs by Methodological Index for Non-Randomized Studies scale (MINORS), which has a range of scores from 0 to 24 [12]. Unified consensus was obtained if there were any different opinions.

\section{Data extraction}

The relevant data, including the authors, year of publication, country, baseline information of participants, prosthesis design, revision rate, power analysis, and the 


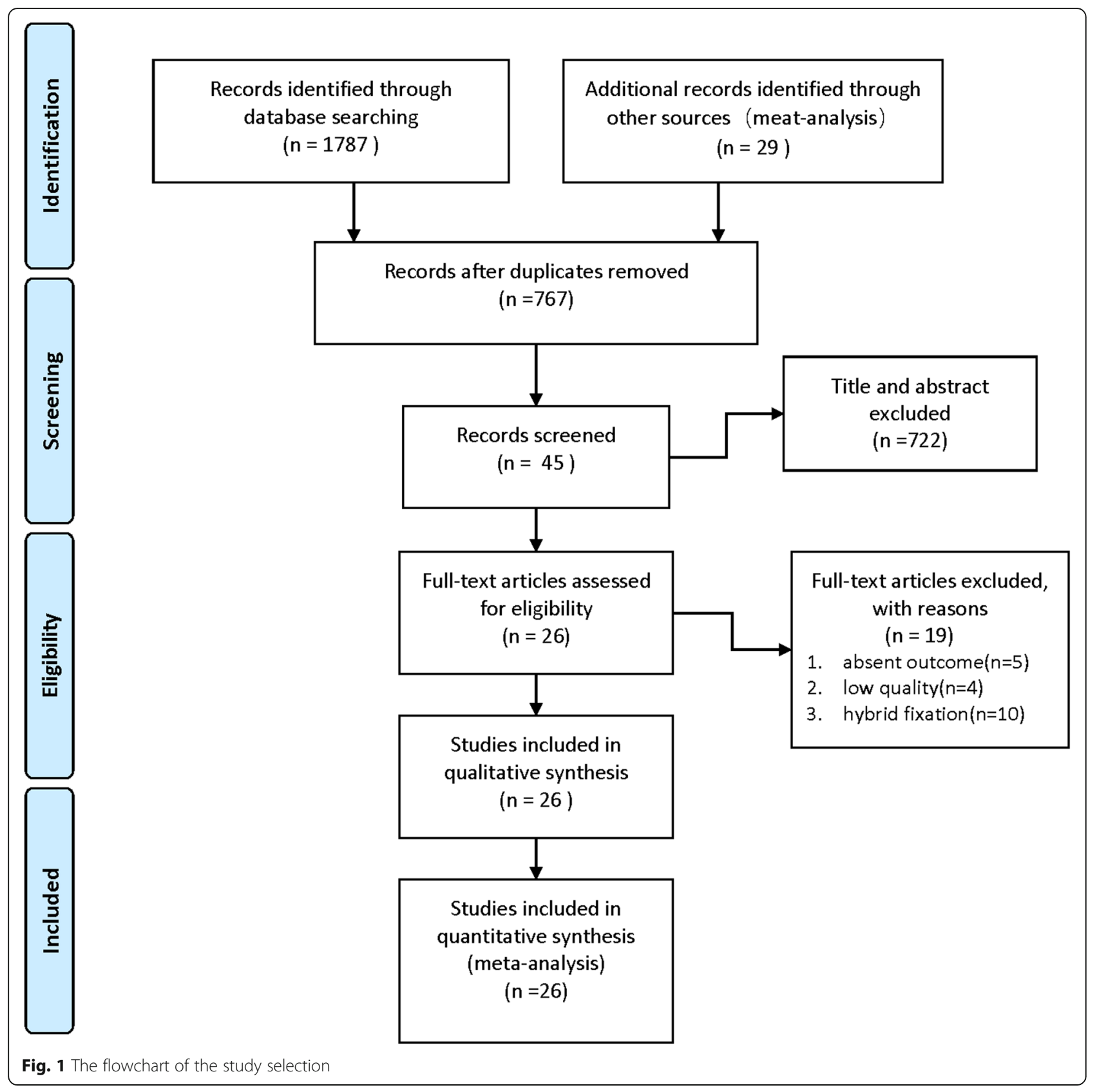

length of follow-up were independently extracted by two reviewers using a standard data extraction form.

To compare the two kinds of fixation in TKA, the outcomes were summarized in three parts. The first part was the rate of revision and reasons of revision, which was the primary outcome of our study. The second part was the postoperative functional recovery, including the Knee Society (KSS) knee and function scores, Oxford knee scores, range of motion (ROM), and manipulation under anesthesia. The third part was the rate of complication, including deep vein thrombosis (DVT) and all infection (including superficial wound infection and periprosthetic joint infection).

\section{Statistical analysis}

The Review Manager 5.3 (Nordic Cochrane Center, Copenhagen, Denmark) was used to perform the metaanalysis. The final results were shown in Forest plots. Mean differences (MD) or standard mean differences 
Table 1 The baseline information of studies compared cementless with cement fixation in TKA

\begin{tabular}{|c|c|c|c|c|c|c|c|c|c|c|}
\hline \multirow[b]{2}{*}{ Studies } & \multirow[b]{2}{*}{ country } & \multirow[b]{2}{*}{$\begin{array}{l}\text { Study } \\
\text { design }\end{array}$} & \multicolumn{5}{|c|}{ Cementless/cement } & \multirow[b]{2}{*}{ Prosthesis } & \multirow[b]{2}{*}{$\begin{array}{l}\text { Power } \\
\text { analysis }\end{array}$} & \multirow[b]{2}{*}{$\begin{array}{l}\text { Follow- } \\
\text { up }\end{array}$} \\
\hline & & & Cases & Age & BMI & Female & $\begin{array}{l}\text { Revision } \\
\text { rate(\%) }\end{array}$ & & & \\
\hline Abu-rajab 2006 [23] & UK & Non-RCT & $20 / 18$ & $69 / 71$ & - & $11 / 8$ & - & - & Y & 2 years \\
\hline Anis 2019 [24] & USA & Non-RCT & $\begin{array}{l}133 / \\
132\end{array}$ & $60 / 62$ & $33 / 33$ & $51 / 44$ & $2.3 / 1.5$ & - & $\mathrm{N}$ & 2 years \\
\hline Bagsby 2016 [25] & USA & Non-RCT & $\begin{array}{l}145 / \\
154\end{array}$ & $\begin{array}{l}62.7 / \\
58.8\end{array}$ & $44.7 / 45.6$ & $\begin{array}{l}102 / \\
122\end{array}$ & $0.7 / 13$ & $\begin{array}{l}\text { Stryker } \\
\text { Triathlon }\end{array}$ & N & $\begin{array}{l}3.65 \\
\text { years }\end{array}$ \\
\hline Baker 2007 [13] & UK & $\mathrm{RCT}$ & $\begin{array}{l}224 / \\
277\end{array}$ & $71 / 70$ & & $\begin{array}{l}103 / \\
121\end{array}$ & $8.9 / 8.7$ & PFC & $\mathrm{N}$ & 8.7 years \\
\hline Boyle et al. 2017 [26] & USA & Non-RCT & $\begin{array}{l}154 / \\
171\end{array}$ & $\begin{array}{l}59.6 / \\
64.9\end{array}$ & $37.4 / 37.4$ & $97 / 128$ & $3.9 / 3.5$ & $\begin{array}{l}\text { Stryker } \\
\text { Triathlon }\end{array}$ & N & 5.7 years \\
\hline Carlsson 2005 [14] & Sweden & $\mathrm{RCT}$ & $27 / 29$ & $74 / 72$ & - & $20 / 22$ & $3.7 / 0$ & PFC & $\mathrm{N}$ & 5 years \\
\hline Dodd 1990 [27] & UK & Non-RCT & 18/18 & - & - & $15 / 15$ & $5.6 / 5.6$ & PCA & $\mathrm{N}$ & 5 years \\
\hline Duffy 1998 [28] & USA & Non-RCT & $55 / 51$ & $54 / 65$ & $\begin{array}{l}29.07 / \\
27.63\end{array}$ & $23 / 24$ & $16.4 / 5.9$ & PFC & $\mathrm{N}$ & $\begin{array}{l}10.2 \\
\text { years }\end{array}$ \\
\hline $\begin{array}{l}\text { Fernandez-Fairen } 2013 \\
\text { [15] }\end{array}$ & Switzerland & $\mathrm{RCT}$ & $74 / 71$ & $61 / 60$ & $29.1 / 30.5$ & $55 / 54$ & $0 / 1.6$ & NexGen CR & Y & 5 years \\
\hline Fricka 2015 [16] & USA & $\mathrm{RCT}$ & $47 / 46$ & $\begin{array}{l}60.2 / \\
58.6\end{array}$ & $31.4 / 32.7$ & $29 / 33$ & $2.1 / 2.2$ & NexGen CR & Y & 2 years \\
\hline Fricka 2019 [17] & USA & $\mathrm{RCT}$ & $41 / 44$ & $\begin{array}{l}59.8 / \\
58.4\end{array}$ & $31.4 / 31.9$ & $26 / 31$ & $4.9 / 2.3$ & NexGen CR & Y & 5 years \\
\hline Gao 2009 [18] & Sweden & $\mathrm{RCT}$ & $19 / 22$ & - & - & - & $5.3 / 0$ & NexGen CR & Y & 2 years \\
\hline Kamath 2011 [29] & USA & Non-RCT & $\begin{array}{l}100 / \\
312\end{array}$ & $55 / 63$ & - & - & $2 / 1.6$ & NexGen CR & N & 5 years \\
\hline Karachalios 2018 [30] & Greek & Non-RCT & $54 / 54$ & $\begin{array}{l}63.2 / \\
63.8\end{array}$ & $32 / 31.5$ & $36 / 37$ & - & aMP system & Y & 8.6 years \\
\hline Khaw 2002 [19] & UK & $\mathrm{RCT}$ & $\begin{array}{l}177 / \\
219\end{array}$ & $71 / 70$ & - & $\begin{array}{l}103 / \\
121\end{array}$ & $3.95 / 4.11$ & PFC & N & 7.3 years \\
\hline Kim 2014 [2] & Korea & $\mathrm{RCT}$ & $80 / 80$ & $\begin{array}{l}54.3 / \\
54.3\end{array}$ & $27.8 / 27.8$ & $63 / 63$ & $1.25 / 0$ & NexGen CR & Y & $\begin{array}{l}16.6 \\
\text { years }\end{array}$ \\
\hline McCaskie 1998 [20] & UK & $\mathrm{RCT}$ & $58 / 81$ & $\begin{array}{l}70.2 / \\
68.8\end{array}$ & - & $32 / 49$ & - & PFC & $\mathrm{N}$ & 5 years \\
\hline Miller et al. 2017 [31] & USA & Non-RCT & $\begin{array}{l}200 / \\
200\end{array}$ & $\begin{array}{l}64.3 / \\
64.4\end{array}$ & $33.9 / 33.1$ & $\begin{array}{l}125 / \\
125\end{array}$ & $3.5 / 4$ & $\begin{array}{l}\text { Stryker } \\
\text { Triathlon }\end{array}$ & N & 5.3 years \\
\hline Nam 2019 [21] & USA & $\mathrm{RCT}$ & $76 / 65$ & $61.3 / 63$ & $31.1 / 31.3$ & $36 / 34$ & $0 / 1.5$ & $\begin{array}{l}\text { Stryker } \\
\text { Triathlon }\end{array}$ & Y & 2 years \\
\hline Pap 2018 [32] & Hungary & Non-RCT & $\begin{array}{l}134 / \\
140\end{array}$ & $59 / 69$ & & $53 / 64$ & $1.5 / 1.4$ & SanatSwing & $\mathrm{N}$ & 2 years \\
\hline Park 2011 [22] & Korea & $\mathrm{RCT}$ & $50 / 50$ & $\begin{array}{l}58.4 / \\
58.4\end{array}$ & $26.6 / 26.6$ & $39 / 39$ & $2 / 0$ & NexGen CR & Y & $\begin{array}{l}13.6 \\
\text { years }\end{array}$ \\
\hline Pecina 2000 [33] & Croatia & Non-RCT & $87 / 44$ & $57 / 62$ & - & - & 22.99/15.91 & PCA & $\mathrm{N}$ & 7.3 years \\
\hline Prudhon 2017 [34] & France & Non-RCT & $\begin{array}{l}100 / \\
100\end{array}$ & $\begin{array}{l}72.3 / \\
73.2\end{array}$ & - & $57 / 59$ & $5 / 10$ & $\begin{array}{l}\text { NEW WAVE } \\
\text { TM }\end{array}$ & $\mathrm{N}$ & $\begin{array}{l}12.1 \\
\text { years }\end{array}$ \\
\hline Rand 1991 [35] & USA & Non-RCT & $59 / 59$ & $57 / 66$ & $29.4 / 24.4$ & $24 / 25$ & - & PFC & N & 2.8 years \\
\hline Rosenberg 1990 [36] & USA & Non-RCT & $\begin{array}{l}132 / \\
139\end{array}$ & $59 / 70$ & & $77 / 82$ & $4.5 / 5.8$ & - & $\mathrm{N}$ & 3.6 years \\
\hline $\begin{array}{l}\text { Sinicrope et al. } 2018 \\
\text { [37] }\end{array}$ & USA & Non-RCT & $108 / 85$ & $62 / 60$ & $45.6 / 45$ & $82 / 67$ & $4.63 / 25.88$ & $\begin{array}{l}\text { Stryker } \\
\text { Triathlon }\end{array}$ & Y & 5 years \\
\hline
\end{tabular}

$R C T$ randomized controlled trial, $B M I$ body mass index, $P F C$ press-fit condylar, $P C A$ porous-coated anatomic, $C R$ cruciate-retaining 
Table 2 The quality assessment of RCTs

\begin{tabular}{llllll}
\hline Studies & Randomization & Concealment of allocation & Double blinding & Withdrawal and dropout & Total score \\
\hline Baker 2007 [13] & 1 & 2 & 2 & 1 & 6 \\
Carlsson 2005 [14] & 2 & 2 & 1 & 1 & 6 \\
Fernandez-Fairen 2013 [15] & 2 & 2 & 2 & 1 & 7 \\
Fricka 2015 [16] & 2 & 2 & 1 & 1 & 6 \\
Fricka 2019 [17] & 2 & 2 & 1 & 1 & 6 \\
Gao 2009 [18] & 2 & 2 & 1 & 1 & 6 \\
Khaw 2002 [19] & 1 & 2 & 2 & 1 & 7 \\
Kim 2014 [2] & 2 & 2 & 2 & 1 & 7 \\
McCaskie 1998[20] & 1 & 2 & 1 & 1 \\
Nam 2019 [21] & 2 & 2 & 2 & 1 & 7 \\
Park 2011 [22] & 2 & 2 & 2 & 1 & \\
\hline
\end{tabular}

(SMD) were used to weigh the effect size for continuous outcomes, and relative risks (RR) were used for dichotomous outcomes. The $I^{2}$ statistic was used to test for heterogeneity across the included studies [11]. A $p$ value $\leq 0.1$ or an $I^{2}>50 \%$ was regarded as proof of heterogeneity. A random-effects model is used to synthesize results with high heterogeneity and is more conservative than a fixed effects model. Therefore, a random-effects model was used to alleviate the effect caused by high heterogeneity, and a fixed effects model was used when statistical evidence showed low heterogeneity.

\section{Results}

\section{Search results}

As shown in Fig. 1, a total of 1787 articles were obtained from the databases via the search strategy. After removing duplicates, 767 articles were screened. From among them, 722 articles were removed after reading the title and abstract based on the inclusion criteria. Then, 19 studies were excluded on the basis of exclusion criteria. Finally, 11 RCTs [2, 13-22] and 15 non-RCTs [23-37] were included in this study.

\section{Baseline information and quality assessment}

Twenty-six studies [2, 13-37] involving 2369 patients in cementless group and 2654 patients in cemented group were included in this review and metaanalysis. The baseline information including study design, demographical data, revision rate, prosthesis, and length of follow-up were clearly listed in Table 1. Especially, the duration of follow-up was same for cemented and cementless groups. And the length of the follow-up in all included studies ranged from 2 years to 16.6 years.

The JADAD score of 11 RCTs were listed in Table 2, both of them were $\geqq 5$, four of them $[2,15,21,22]$ got 7 points. The MINORS scores of 15 non-RCTs were listed in Table 3, both of them were $\geqq 20$, only 1 of them [37] got 24 points.

\section{Rate of revision and reasons of revision}

A total of 20 studies involving 1925 patients in cementless group and 2203 patients in cemented group reported the rate of revision during the followup. There were $95(4.9 \%)$ patients in the cementless group and $89(4 \%)$ patients in the cemented group underwent the revision for all kinds of reasons. Pooled results shown that there was no significant difference between the rate of revision during the at least 2 years of follow-up in two groups $(R R=1.09$, $95 \%$ CI $[0.82,1.44], p=0.55$; Fig. 2).

Among reasons that caused revision, aseptic loosing was the most common, next was the periprosthetic joint infection (PJI). Fifteen studies with 1697 patients in the cementless group and 1999 patients in the cemented group recorded the rate of aseptic loosing caused the revision $(49(2.9 \%)$ and $47(2.4 \%)$, respectively). Pooled result presented that there was no significant difference in two groups $(\mathrm{RR}=1.03,95 \% \mathrm{CI}$ $[0.7,1.52], P=0.88$; Fig. 3). Sixteen studies with 1777 patients in the cementless group and 2032 patients in the cemented group reported the rate of PJI caused the revision (20 (1.1\%) and 27(1.3\%), respectively). Pooled result presented that there was no significant difference in two groups ( $R R=0.81,95 \%$ CI $[0.47$, 1.4], $p=0.45$; Fig. 4). The specific number of revisions and other reasons were listed in Table 4 in detail.

\section{Functional recovery}

Twelve studies involving 827 patients in cementless group and 819 patients in cemented group recorded the 


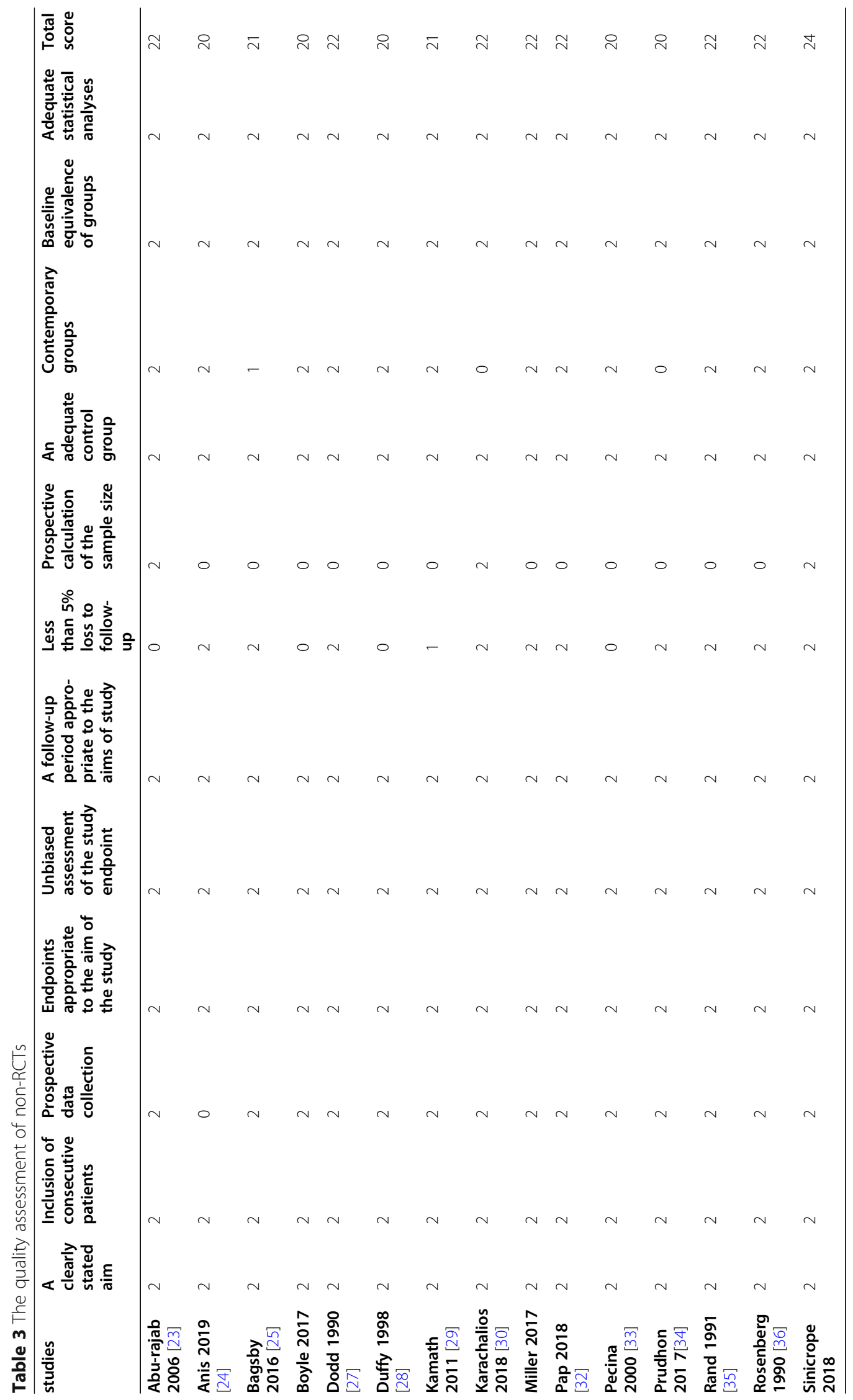




\begin{tabular}{|c|c|c|c|c|c|c|c|c|c|c|}
\hline Study or Subgroup & \multicolumn{2}{|c|}{ cementless } & \multicolumn{2}{|c|}{ cemented } & Weight & $\begin{array}{c}\text { Risk Ratio } \\
\text { M-H. Fixed. 95\% Cl }\end{array}$ & \multicolumn{4}{|c|}{$\begin{array}{c}\text { Risk Ratio } \\
\text { M-H. Fixed. 95\% Cl }\end{array}$} \\
\hline Anis2019 & 3 & 133 & 2 & 132 & $2.3 \%$ & $1.49[0.25,8.77]$ & & & & \\
\hline Baker2007 & 20 & 224 & 24 & 277 & $24.4 \%$ & $1.03[0.58,1.82]$ & & & & \\
\hline Boyle2017 & 6 & 154 & 6 & 171 & $6.5 \%$ & $1.11[0.37,3.37]$ & & & & \\
\hline Carlsson2005 & 1 & 27 & 0 & 29 & $0.5 \%$ & $3.21[0.14,75.68]$ & & & & \\
\hline Dodd1990 & 1 & 18 & 1 & 18 & $1.1 \%$ & $1.00[0.07,14.79]$ & & & & \\
\hline Duffy1998 & 9 & 55 & 3 & 51 & $3.5 \%$ & $2.78[0.80,9.71]$ & & & & \\
\hline Fernandez-Fairen2013 & 0 & 71 & 1 & 64 & $1.8 \%$ & $0.30[0.01,7.26]$ & & & & \\
\hline Fricka2015 & 1 & 47 & 1 & 46 & $1.1 \%$ & $0.98[0.06,15.19]$ & & & & \\
\hline Fricka2019 & 2 & 41 & 1 & 44 & $1.1 \%$ & $2.15[0.20,22.79]$ & & & & \\
\hline Gao2009 & 1 & 19 & 0 & 22 & $0.5 \%$ & $3.45[0.15,80.03]$ & & & & \\
\hline Kamath 2011 & 2 & 100 & 5 & 312 & $2.8 \%$ & $1.25[0.25,6.33]$ & & & & \\
\hline Khaw2002 & 7 & 177 & 9 & 219 & $9.2 \%$ & $0.96[0.37,2.53]$ & & & & \\
\hline Kim2014 & 1 & 80 & 0 & 80 & $0.6 \%$ & $3.00[0.12,72.56]$ & & & & \\
\hline Miller2017 & 7 & 200 & 8 & 200 & $9.1 \%$ & $0.88[0.32,2.37]$ & & & & \\
\hline Nam2019 & 0 & 76 & 1 & 65 & $1.8 \%$ & $0.29[0.01,6.90]$ & & & & \\
\hline Pap2018 & 2 & 134 & 2 & 140 & $2.2 \%$ & $1.04[0.15,7.31]$ & & & & \\
\hline Park2011 & 1 & 50 & 0 & 50 & $0.6 \%$ & $3.00[0.13,71.92]$ & & & & \\
\hline Pecina2000 & 20 & 87 & 7 & 44 & $10.6 \%$ & $1.44[0.66,3.15]$ & & & & \\
\hline Prudhon 2017 & 5 & 100 & 10 & 100 & $11.4 \%$ & $0.50[0.18,1.41]$ & & & - & \\
\hline Rosenberg1990 & 6 & 132 & 8 & 139 & $8.9 \%$ & $0.79[0.28,2.22]$ & & & & \\
\hline Total $(95 \% \mathrm{Cl})$ & & 1925 & & 2203 & $100.0 \%$ & $1.09[0.82,1.44]$ & & & & \\
\hline Total events & 95 & & 89 & & & & & & & \\
\hline $\begin{array}{l}\text { Heterogeneity: } \mathrm{Chi}^{2}=9 . \\
\text { Test for overall effect: } Z\end{array}$ & $\begin{array}{l}2 . d f=19( \\
0.59(P=\end{array}$ & $\begin{array}{l}P=0.97 \\
0.55)\end{array}$ & 7); $\left.\right|^{2}=09$ & & & & $\frac{1}{0.01}$ & $\begin{array}{l}0.1 \\
\text { cementless }\end{array}$ & $1 \quad 10$ & $\frac{1}{100}$ \\
\hline
\end{tabular}

\begin{tabular}{|c|c|c|c|c|c|c|c|c|c|c|}
\hline Study or Subgroup & \multicolumn{2}{|c|}{ cementless } & \multicolumn{2}{|c|}{ cemented } & Weight & $\begin{array}{c}\text { Risk Ratio } \\
\text { M-H, Fixed, } 95 \% \mathrm{Cl}\end{array}$ & \multicolumn{4}{|c|}{$\begin{array}{c}\text { Risk Ratio } \\
\text { M-H, Fixed, } 95 \% \mathrm{Cl}\end{array}$} \\
\hline Bagsby2016 & 0 & 145 & 9 & 154 & $19.2 \%$ & $0.06[0.00,0.95]$ & & & & \\
\hline Baker2007 & 12 & 224 & 14 & 277 & $26.0 \%$ & $1.06[0.50,2.25]$ & & & 1 & \\
\hline Boyle2017 & 2 & 154 & 1 & 171 & $2.0 \%$ & $2.22[0.20,24.25]$ & & & & \\
\hline Dodd1990 & 1 & 18 & 1 & 18 & $2.1 \%$ & $1.00[0.07,14.79]$ & & & & \\
\hline Duffy'1998 & 8 & 55 & 2 & 51 & $4.3 \%$ & $3.71[0.83,16.65]$ & & & & \\
\hline Fricka2019 & 1 & 41 & 0 & 44 & $1.0 \%$ & $3.21[0.13,76.74]$ & & & & \\
\hline Kamath 2011 & 0 & 100 & 2 & 312 & $2.5 \%$ & $0.62[0.03,12.80]$ & & & & \\
\hline Khaw 2002 & 3 & 177 & 1 & 219 & $1.9 \%$ & $3.71[0.39,35.38]$ & & & & \\
\hline Kim2014 & 1 & 80 & 0 & 80 & $1.0 \%$ & $3.00[0.12,72.56]$ & & & & \\
\hline Miller2017 & 1 & 200 & 5 & 200 & $10.4 \%$ & $0.20[0.02,1.70]$ & & & - & \\
\hline Pap2018 & 2 & 134 & 2 & 140 & $4.1 \%$ & $1.04[0.15,7.31]$ & & & & \\
\hline Park2011 & 1 & 50 & 0 & 50 & $1.0 \%$ & $3.00[0.13,71.92]$ & & & & \\
\hline Pecina2000 & 13 & 87 & 4 & 44 & $11.0 \%$ & $1.64[0.57,4.75]$ & & & & \\
\hline Prudhon2017 & 2 & 100 & 6 & 100 & $12.5 \%$ & $0.33[0.07,1.61]$ & & & & \\
\hline Rosenberg1990 & 2 & 132 & 0 & 139 & $1.0 \%$ & $5.26[0.26,108.61]$ & & & & \\
\hline Sinicrope2018 & 1 & 108 & 16 & 85 & $0.0 \%$ & $0.05[0.01,0.36]$ & & & & \\
\hline Total $(95 \% \mathrm{Cl})$ & & 1697 & & 1999 & $100.0 \%$ & $1.03[0.70,1.52]$ & & & & \\
\hline Total events & 49 & & 47 & & & & & & & \\
\hline $\begin{array}{l}\text { Heterogeneity: } \mathrm{Chi}^{2}= \\
\text { Test for overall effect }\end{array}$ & $\begin{array}{l}16.06, d f \\
Z=0.15(\end{array}$ & $\begin{array}{l}14(P= \\
=0.88)\end{array}$ & $=0.31) ; i^{2}$ & $=13 \%$ & & & 0.002 & $\begin{array}{c}0.1 \\
\text { cementless }\end{array}$ & $1 \frac{10}{\text { cemented }}$ & 500 \\
\hline
\end{tabular}




\begin{tabular}{|c|c|c|c|c|c|c|c|c|c|c|}
\hline \multirow[b]{2}{*}{ Studv or Subgroup } & \multicolumn{2}{|c|}{ cementless } & \multicolumn{2}{|c|}{ cemented } & \multirow{2}{*}{ Weight } & \multirow{2}{*}{$\begin{array}{c}\text { Risk Ratio } \\
\text { M-H. Fixed, 95\% Cl }\end{array}$} & \multirow{2}{*}{\multicolumn{4}{|c|}{$\begin{array}{c}\text { Risk Ratio } \\
\text { M-H.Fixed, 95\% Cl }\end{array}$}} \\
\hline & Events & Total & Events & Total & & & & & & \\
\hline Anis2019 & 3 & 133 & 2 & 132 & $6.8 \%$ & $1.49[0.25,8.77]$ & & & & \\
\hline Bagsby2016 & 1 & 145 & 2 & 154 & $6.6 \%$ & $0.53[0.05,5.79]$ & & & & \\
\hline Baker2007 & 4 & 224 & 7 & 277 & $21.3 \%$ & $0.71[0.21,2.38]$ & & & - & \\
\hline Boyle2017 & 1 & 154 & 2 & 171 & $6.4 \%$ & $0.56[0.05,6.06]$ & & & & \\
\hline Carlsson 2005 & 1 & 27 & 0 & 29 & $1.6 \%$ & $3.21[0.14,75.68]$ & & & & \\
\hline Duffy 1998 & 0 & 55 & 1 & 51 & $5.3 \%$ & $0.31[0.01,7.43]$ & & & & \\
\hline Fernandez-Fairen2013 & 0 & 71 & 1 & 64 & $5.4 \%$ & $0.30[0.01,7.26]$ & & & & \\
\hline Fricka2015 & 0 & 47 & 1 & 46 & $5.2 \%$ & $0.33[0.01,7.81]$ & & & & \\
\hline Fricka2019 & 0 & 41 & 1 & 44 & $4.9 \%$ & $0.36[0.01,8.53]$ & & & & \\
\hline Kamath2011 & 0 & 100 & 2 & 312 & $4.1 \%$ & $0.62[0.03,12.80]$ & & & & \\
\hline Khaw 2002 & 1 & 177 & 5 & 219 & $15.2 \%$ & $0.25[0.03,2.10]$ & & & 一 & \\
\hline Miller2017 & 1 & 200 & 0 & 200 & $1.7 \%$ & $3.00[0.12,73.20]$ & & & & \\
\hline Nam2019 & 0 & 76 & 1 & 65 & $5.5 \%$ & $0.29[0.01,6.90]$ & & & & \\
\hline Pecina2000 & 3 & 87 & 1 & 44 & $4.5 \%$ & $1.52[0.16,14.17]$ & & & & \\
\hline Rosenberg1990 & 1 & 132 & 0 & 139 & $1.7 \%$ & $3.16[0.13,76.84]$ & & & & \\
\hline Sinicrope 2018 & 4 & 108 & 1 & 85 & $3.8 \%$ & $3.15[0.36,27.65]$ & & & & \\
\hline Total $(95 \% \mathrm{Cl})$ & & 1777 & & 2032 & $100.0 \%$ & $0.81[0.47,1.40]$ & & & & \\
\hline Total events & 20 & & 27 & & & & & & & \\
\hline $\begin{array}{l}\text { Heterogeneity: } \mathrm{Chi}^{2}=7 . \\
\text { Test for overall effect: } Z\end{array}$ & $\begin{array}{l}1, d f=15 \\
0.75(P=\end{array}$ & $\begin{array}{l}P=0.9 \\
0.45)\end{array}$ & 14); $i^{2}=09$ & & & & 0.001 & $\begin{array}{c}0.1 \\
\text { cementless }\end{array}$ & 10 & 1000 \\
\hline
\end{tabular}

Knee Society knee score. Pooled results revealed there was no significant difference regarding Knee Society knee score between two groups (MD $=0.69,95 \%$ CI $[-$ 0.97, 2.35], $p=0.42$; Fig. 5a). Nine studies involving 652 patients in cementless group and 656 patients in cemented group recorded the Knee Society function score, which was significantly higher in the former group (MD $=1.70,95 \%$ CI $[0.53,2.86], p=0.004$; Fig. 5b). Four studies involving 176 patients in cementless group and 167 patients in cemented group recorded the Oxford knee score. Pooled results revealed that the kind of fixation did not make a difference on Oxford knee score in short duration $(\mathrm{MD}=-0.62,95 \% \mathrm{CI}[-1.71,0.47], p=$ 0.27; Fig. 5c).

Seven studies involving 626 patients in cementless group and 679 patients in cemented group reported the range of motion (ROM) following TKA. Pooled results revealed the ROM was not significantly different in two groups $(\mathrm{MD}=0.9,95 \% \mathrm{CI}[-0.72,2.52]$, $P=0.28$; Fig. 6a). However, 7 studies involving 566 patients in the cementless group and 588 patients in the cemented group revealed that the rate of manipulation under anesthesia was significantly more in the cemented group $(\mathrm{RR}=0.44,95 \%$ CI $[0.24,0.80], p=$ 0.007; Fig. 6b).

\section{Complications}

Five studies involving 369 patients in cementless group and 390 patients in cemented group recorded the rate of deep vein thrombosis (DVT) following TKA. There were $17(4.6 \%)$ in cementless group and 27 (6.9\%) in cemented group diagnosed as DVT, while it was not significantly different $(\mathrm{RR}=0.81,95 \% \mathrm{CI}[0.47,1.39], p=0.44$; Fig. 7a). Twenty studies involving 2048 patients in the cementless group and 2337 patients in the cemented group recorded the rate of all infection following TKA. There were $29(1.4 \%)$ patients in the cementless group and $32(1.4 \%)$ patients in the cemented group diagnosed as superficial 3rwound infection or PJI. The pooled results shown insignificant difference $(\mathrm{RR}=0.97,95 \% \mathrm{CI}$ [0.61, 1.57], $P=0.92$; Fig. 7b).

\section{Discussion}

Compared with the published review and meta-analysis [38-42], the most prominent advantage of our study was that a minimum 2 years length of follow-up criteria was used for screening studies and analyzing these together.

Survivorship of prosthesis was the most important endpoint in TKA [43]. Rate of revision and reasons caused revision were primary outcomes in our study. Although the pooled results shown insignificant difference, the cementless fixation presented significant superiority in studies followed more than 2 years and less than 5.5 years. In addition, although a relatively longer follow-up was needed to compare the true difference regarding the rate of revision between two kinds of fixation in TKA. It has been reported that 3 to $50 \%$ primary TKAs underwent revision within the first 5 years $[44,45]$. More than 


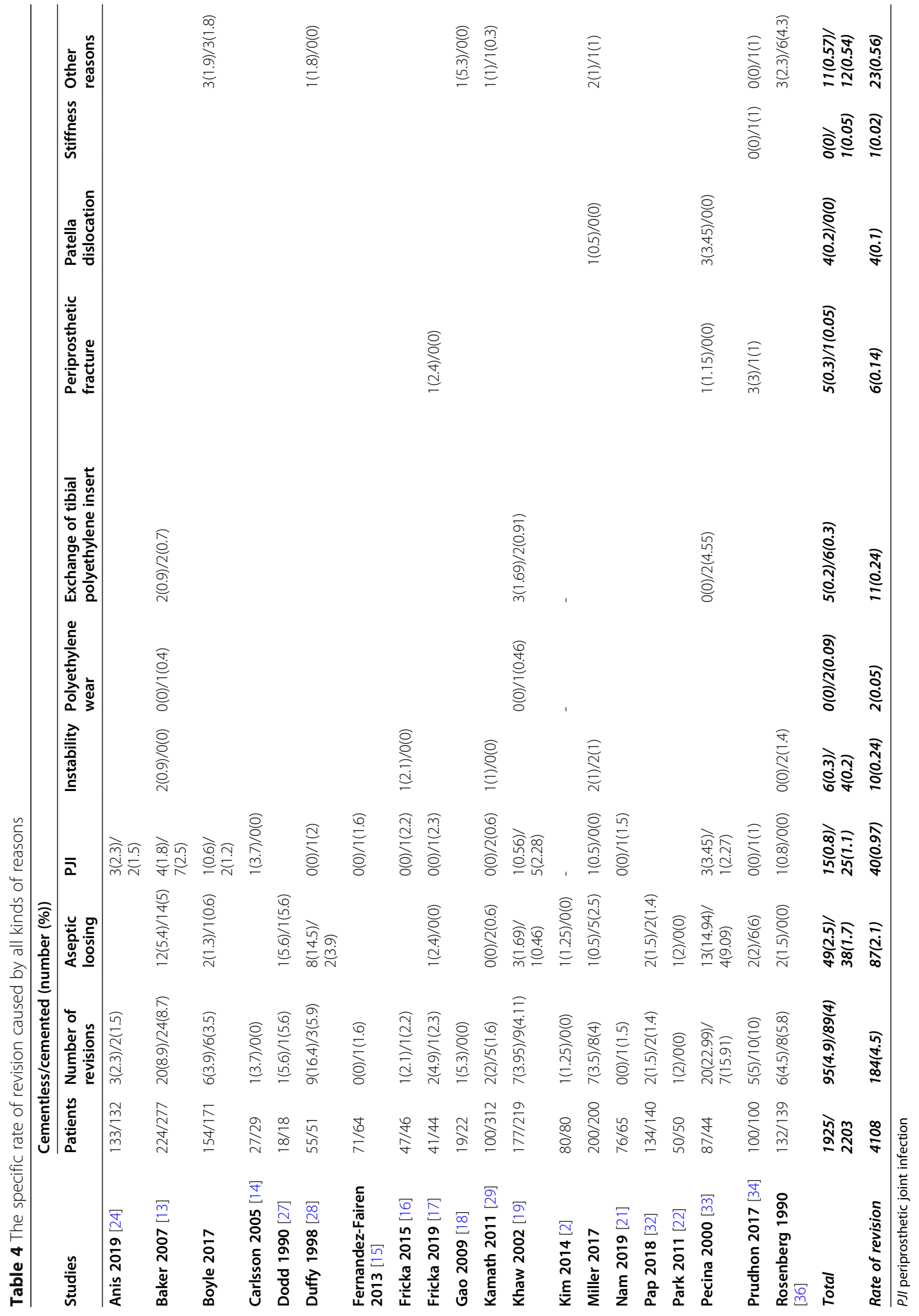




\section{A. Knee Society knee scores}

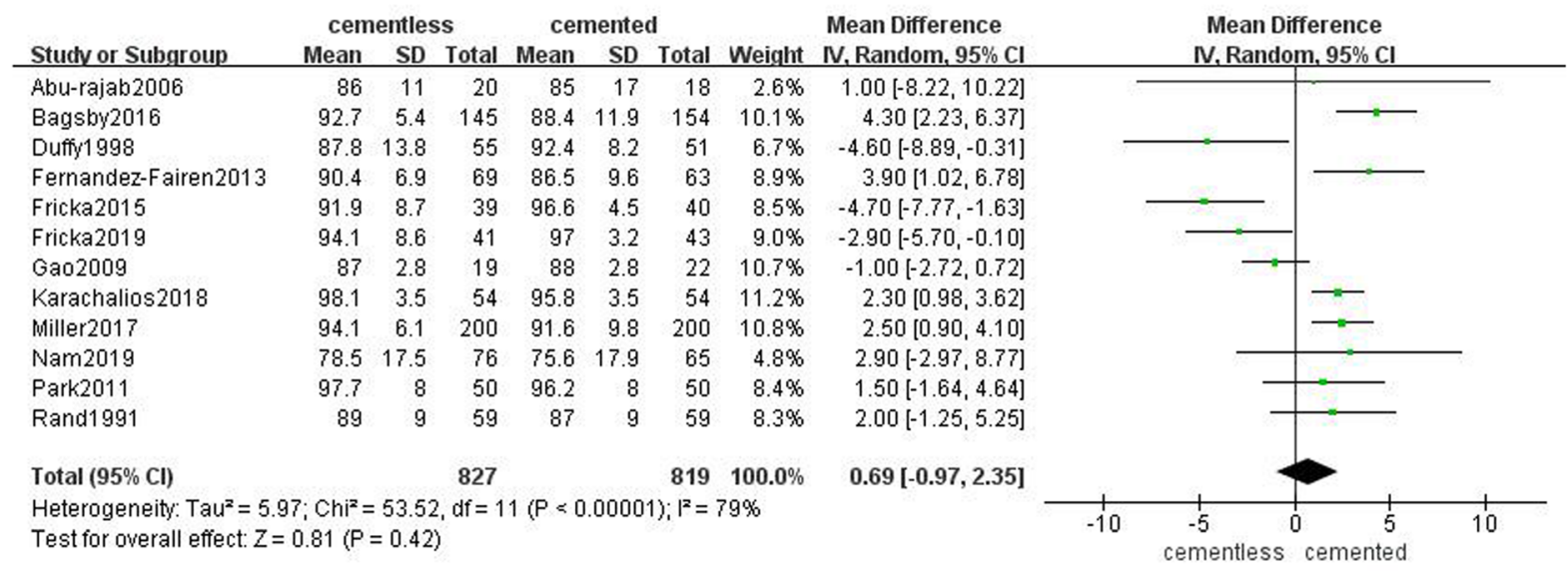

B. Knee Society function scores

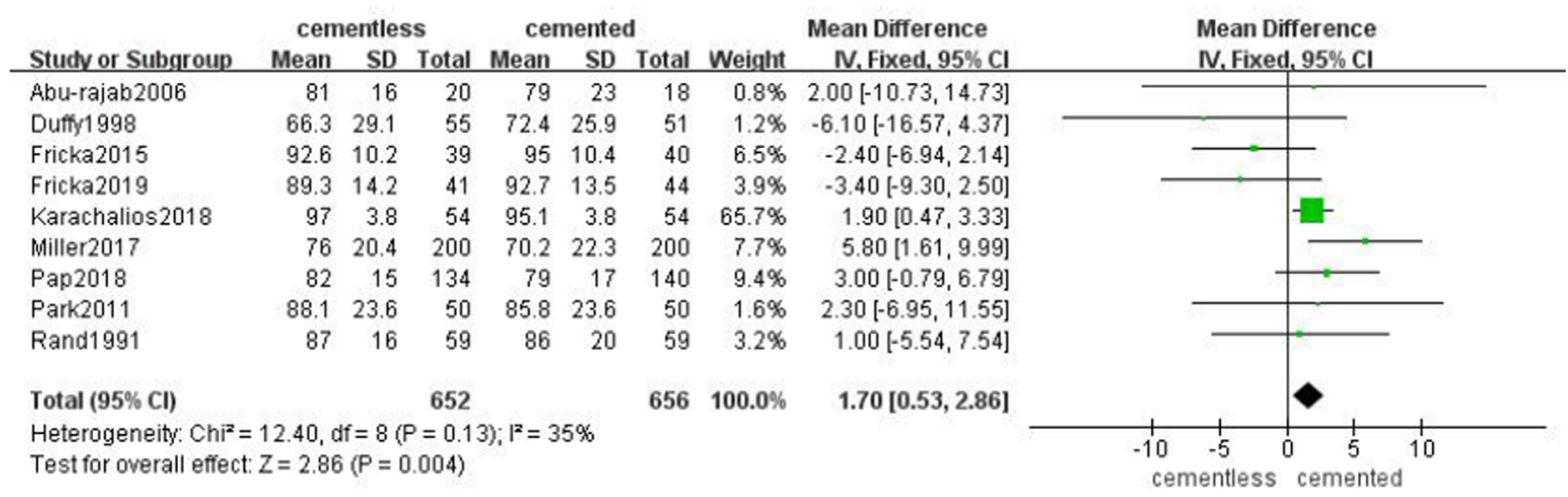

\section{Oxford knee scores}

\begin{tabular}{|c|c|c|c|c|c|c|c|c|c|}
\hline \multirow[b]{2}{*}{ Stucty or Subgroup } & \multicolumn{3}{|c|}{ cementless } & \multicolumn{3}{|c|}{ cemented } & \multicolumn{2}{|r|}{ Mean Difference } & \multirow{2}{*}{$\begin{array}{l}\text { Mean Difference } \\
\text { N } \text {, Fixed, } 95 \% \mathrm{Cl}\end{array}$} \\
\hline & Mean & SD & Total & Mean & SD & Total & Weight & IV, Fixed, $95 \% \mathrm{Cl}$ & \\
\hline Abu-rajab2006 & 24 & 6 & 20 & 23 & 9 & 18 & $4.9 \%$ & $1.00[-3.92,5.92]$ & \\
\hline Fricka2015 & 43.1 & 4.8 & 39 & 44.7 & 4.1 & 40 & $30.6 \%$ & $-1.60[-3.57,0.37]$ & t \\
\hline Fricka2019 & 44 & 3.8 & 41 & 44.8 & 3.5 & 44 & $49.1 \%$ & $-0.80[-2.36,0.76]$ & \\
\hline Nam2019 & 41 & 7.5 & 76 & 39.6 & 9.1 & 65 & $15.4 \%$ & $1.40[-1.38,4.18]$ & \\
\hline Total $(95 \% \mathrm{Cl})$ & & & 176 & & & 167 & $100.0 \%$ & $-0.62[-1.71,0.47]$ & \\
\hline \multicolumn{9}{|c|}{$\begin{array}{l}\text { Heterogeneity: } \mathrm{Chi}^{2}=3.44, \mathrm{df}=3(P=0.33) ; \mathrm{I}^{2}=13 \% \\
\text { Test for overall effect: } Z=1.11(P=0.27)\end{array}$} & $\begin{array}{cccc}1 & 1 & 1 & 1 \\
-4 & -2 & 0 & 2 \\
\text { cementless } & \text { cemente }\end{array}$ \\
\hline
\end{tabular}

Fig. 5 The frost blot about the functional recovery

8 kinds of reasons that caused revision after TKA were found, aseptic loosing was the most common. Among all causes of revision, rate of aseptic loosing was $2.1 \%$, followed by the periprosthetic joint infection (PJI, $0.97 \%)$, instability $(0.24 \%)$, exchange of tibia polyethylene insert $(0.24 \%)$, periprosthetic fracture $(0.14 \%)$, patella dislocation $(0.1 \%)$, polyethylene wear $(0.05 \%)$, stiffness $(0.02 \%)$, and other reasons $(0.56 \%)$. Consistent with the rate of revision, rate of aseptic loosing was significantly decreased in the cementless fixation in studies followed more than 2 years and less than 5 years. However, other reasons including PJI were not significantly different between two groups. Therefore, it is induced that aseptic loosing was possibly easier happened in bone-cement interface.

In terms of functional recovery after TKA, patients in cementless group had better Knee Function Score compared with patients in cemented group. Although ROM 
A. Range of motion (ROM)

\begin{tabular}{|c|c|c|c|c|c|c|c|c|c|c|c|}
\hline \multirow[b]{2}{*}{ Stucty or Subgroup } & \multicolumn{3}{|c|}{ cementless } & \multicolumn{3}{|c|}{ cemented } & \multirow[b]{2}{*}{ Weight } & \multicolumn{2}{|l|}{ Mean Difference } & \multirow{2}{*}{$\begin{array}{l}\text { Mean Difference } \\
\text { IV, Fixed, } 95 \% \mathrm{Cl}\end{array}$} & \\
\hline & Mean & SD & Total & Mean & SD & Total & & IV, Fixed, $95 \% \mathrm{Cl}$ & & & \\
\hline Boyle2017 & 115 & 9.95 & 154 & 114.3 & 9.27 & 171 & $59.6 \%$ & $0.70[-1.40,2.80]$ & & & \\
\hline Dodd1990 & 106 & 7.5 & 18 & 104 & 12.5 & 18 & $5.8 \%$ & $2.00[-4.73,8.73]$ & & & \\
\hline Kim2014 & 125 & 23.9 & 80 & 128 & 23.9 & 80 & $4.8 \%$ & $-3.00[-10.41,4.41]$ & & & \\
\hline McCaskie1998 & 100 & 24 & 58 & 105.8 & 11 & 81 & $6.0 \%$ & $-5.80[-12.42,0.82]$ & & & \\
\hline Pap2018 & 116 & 23 & 134 & 113 & 21 & 140 & $9.6 \%$ & $3.00[-2.22,8.22]$ & & & \\
\hline Park2011 & 128 & 25.5 & 50 & 124 & 25.5 & 50 & $2.6 \%$ & $4.00[-6.00,14.00]$ & & & \\
\hline Rosenberg1990 & 109 & 15.5 & 132 & 105 & 23.8 & 139 & $11.6 \%$ & $4.00[-0.76,8.76]$ & & & \\
\hline Total $(95 \% \mathrm{Cl})$ & & & 626 & & & 679 & $100.0 \%$ & $0.90[-0.72,2.52]$ & & & \\
\hline \multicolumn{9}{|c|}{$\begin{array}{l}\text { Heterogeneity: } \text { Chi }^{2}=7.75, \mathrm{df}=6(\mathrm{P}=0.26) ;\left.\right|^{2}=23 \% \\
\text { Test for overall effect: } Z=1.09(P=0.28)\end{array}$} & -10 & $\begin{array}{l}-5 \\
\text { mentless cemer }\end{array}$ & 10 \\
\hline
\end{tabular}

B. Manipulation under anesthesia

\begin{tabular}{|c|c|c|c|c|c|c|c|c|c|c|}
\hline Study or Subgroup & \multicolumn{2}{|c|}{ cementless } & \multicolumn{2}{|c|}{ cemented } & \multicolumn{3}{|c|}{ Risk Ratio } & \multicolumn{2}{|c|}{$\begin{array}{c}\text { Risk Ratio } \\
\text { M-H, Fixed, 95\% Cl }\end{array}$} & \\
\hline Boyle2017 & 2 & 154 & 13 & 171 & $36.0 \%$ & $0.17[0.04,0.74]$ & & $=-$ & & \\
\hline Dodd1990 & 1 & 18 & 2 & 18 & $5.8 \%$ & $0.50[0.05,5.04]$ & & & & \\
\hline Fricka2015 & 0 & 47 & 2 & 46 & $7.4 \%$ & $0.20[0.01,3.97]$ & & & & \\
\hline Karachalios2018 & 1 & 54 & 1 & 54 & $2.9 \%$ & $1.00[0.06,15.58]$ & & & & \\
\hline Pap2018 & 4 & 134 & 5 & 140 & $14.3 \%$ & $0.84[0.23,3.05]$ & & & & \\
\hline Prudhon2017 & 6 & 100 & 9 & 100 & $26.3 \%$ & $0.67[0.25,1.80]$ & & $\rightarrow$ & - & \\
\hline Rand1991 & 0 & 59 & 2 & 59 & $7.3 \%$ & $0.20[0.01,4.08]$ & & & & \\
\hline Total $(95 \% \mathrm{Cl})$ & & 566 & & 588 & $100.0 \%$ & $0.44[0.24,0.80]$ & & & & \\
\hline Total events & 14 & & 34 & & & & & & & \\
\hline $\begin{array}{l}\text { Heterogeneity: } \mathrm{Chi}^{2} \\
\text { Test for overall effect }\end{array}$ & $\begin{array}{l}4.08, d f= \\
Z=2.68\end{array}$ & $\begin{array}{l}6(P=0 \\
P=0.00\end{array}$ & $0.67) ; 1^{2}=$ & & & & 0.001 & $\begin{array}{c}0.1 \\
\text { cementless }\end{array}$ & $\begin{array}{c}10 \\
\text { cemented }\end{array}$ & 1000 \\
\hline
\end{tabular}

Fig. 6 The frost blot about the knee motion

was not significantly different, there were significantly less patients in cementless group required manipulation under anesthesia. A possible explanation for the better recovery in cementless TKA was that relevant complications including osteolysis, anterior knee pain was more common in the cemented group. In addition, it is worth noting that the length of follow-up in studies reported the Knee Society Function score was all more than 8.5 years, and also in the studies reported manipulation under anesthesia mostly followed more than 5 years. It could be concluded that cementless fixation might present long-term advantages regarding the functional recovery.

Along with the development of manufacture and biomaterials including highly porous metals, cross-linked polyethylene, and corrections in initial cementless designs, some recent publications show successful results in long-term follow-up of cementless fixation [46]. Interest on cementless fixation increased as more young patients underwent TKA. Moreover, cementless TKA presented lower revision rates compared with cemented fixation in morbidly obese patients [25]. A possible reason was that greater stress was placed on the bone-implant interface when patients were more active or obese [47]. Therefore, inferior performance of cemented TKA in younger and obese patients made the advent of cementless an alternative way to offer long-term fixation. What is more, a study published in 2019 reported that cementless TKA costed much less than cemented TKA [48].

There are several shortcomings in our study. Firstly, studies followed longer than 10 years was not enough. Secondly, the prosthesis design used in included studies was not totally same, which might increase bias of risk. Thirdly, there were only 11 RCTs in 26 studies included in our study decreased the level of evidence.

\section{Conclusion}

Cementless fixation did not decrease the rate of revision after the total knee arthroplasty compared with the cemented fixation, while the long-term functional recovery was significantly better in the cementless group. 


\section{A. Deep Vein Thrombosis}

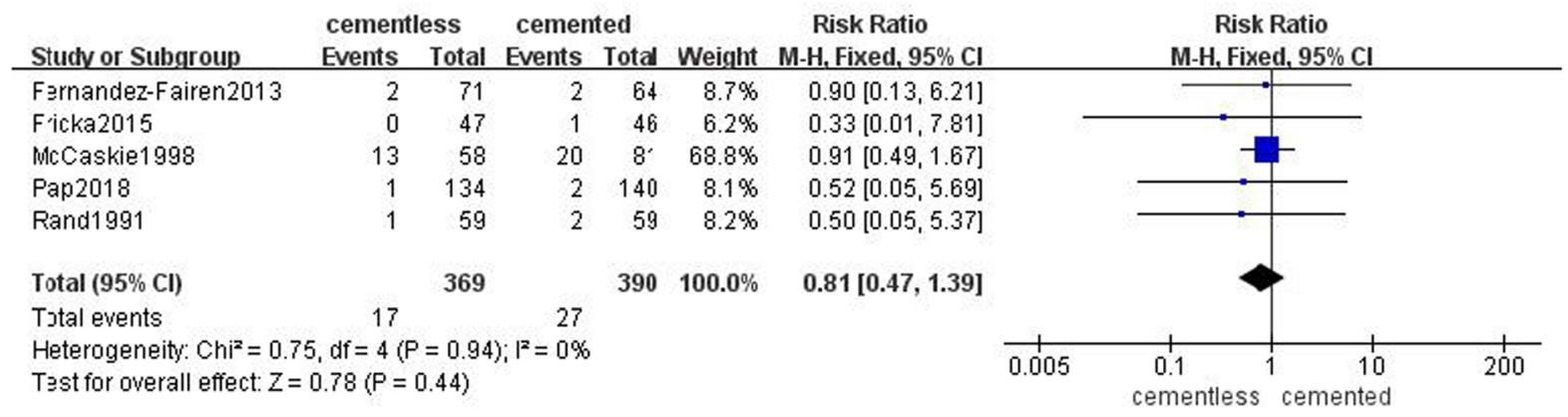

\section{B. All Infection}

\begin{tabular}{|c|c|c|c|c|c|c|c|c|c|c|}
\hline Stuch or Subgroup & cementless & $\begin{array}{l}\text { ess } \\
\text { Total }\end{array}$ & \multicolumn{2}{|c|}{ cemented } & Weight & $\begin{array}{c}\text { Risk Ratio } \\
\text { M-H, Fixed, } 95 \% \mathrm{Cl}\end{array}$ & \multicolumn{3}{|c|}{$\begin{array}{c}\text { Risk Ratio } \\
\text { M-H, Fixed, } 95 \% \text { Cl }\end{array}$} & \\
\hline Aาis2019 & 5 & 133 & 3 & 132 & $8.8 \%$ & $1.65[0.40,6.78]$ & & & & \\
\hline Bagsby 2016 & 1 & 145 & 2 & 154 & $5.7 \%$ & $0.53[0.05,5.79]$ & & & & \\
\hline Baker200? & 4 & 224 & 7 & $27 ?$ & $18.3 \%$ & $0.71[0.21,2.38]$ & & & & \\
\hline Boyle2017 & 1 & 154 & 2 & $17^{\circ}$ & $5.5 \%$ & $0.56[0.05,6.06]$ & & & & \\
\hline Carlsson2005 & 1 & 27 & 0 & 29 & $1.4 \%$ & $3.21[0.14,75.68]$ & & & & \\
\hline Duffy1998 & 1 & 55 & 2 & 5 & $6.1 \%$ & $0.46[0.04,4.96]$ & & & & \\
\hline Fernandez-Fairen 2013 & 0 & 71 & 1 & 64 & $4.6 \%$ & $0.30[0.01,7.26]$ & & & & \\
\hline Ficka2015 & 0 & 47 & 1 & 46 & $4.4 \%$ & $0.33[0.01,7.81]$ & & & & \\
\hline F'icka2019 & 0 & 41 & 1 & 44 & $4.2 \%$ & $0.36[0.01,8.53]$ & & & & \\
\hline Kamath 2011 & 0 & 100 & 2 & 312 & $3.6 \%$ & $0.62[0.03,12.80]$ & & & & \\
\hline Khaw2002 & 3 & 177 & 5 & 219 & $13.1 \%$ & $0.74[0.18,3.06]$ & & & & \\
\hline Km2014 & 1 & 80 & 1 & 80 & $2.9 \%$ & $1.00[0.06,15.71]$ & & & & \\
\hline McCaskie1998 & 1 & 58 & 0 & 8 & $1.2 \%$ & $4.17[0.17,100.57]$ & & & & \\
\hline Miller2017 & 1 & 200 & 0 & 200 & $1.5 \%$ & $3.00[0.12,73.20]$ & & & & \\
\hline Park2011 & 1 & 50 & 1 & 50 & $2.9 \%$ & $1.00[0.06,15.55]$ & & & & \\
\hline Pecina2000 & 3 & 87 & 1 & 44 & $3.9 \%$ & $1.52[0.16,14.17]$ & & & & \\
\hline Prudhon2017 & 0 & 100 & 1 & 100 & $4.4 \%$ & $0.33[0.01,8.09]$ & & & & \\
\hline Rand1991 & 1 & 59 & 1 & 59 & $2.9 \%$ & $1.00[0.06,15.61]$ & & & & \\
\hline Rosenberg1990 & 1 & 132 & 0 & 139 & $1.4 \%$ & $3.16[0.13,76.84]$ & & & & \\
\hline Sinicrope2018 & 4 & 108 & 1 & 85 & $3.3 \%$ & $3.15[0.36,27.65]$ & & & & \\
\hline Total $(95 \% \mathrm{Cl})$ & & 2048 & & 2337 & $100.0 \%$ & $0.97[0.61,1.57]$ & & & & \\
\hline Total events & 29 & & 32 & & & & & & & \\
\hline $\begin{array}{l}\text { Heterogeneity: } \mathrm{Chl}^{2}= \\
\text { Test for overall effect: } Z\end{array}$ & $\begin{array}{l}\text { dt }=1 \mathrm{y} \\
0.11(\mathrm{P}=\end{array}$ & $\begin{array}{l}r=u . y s \\
0.92)\end{array}$ & $y) ; 1^{2}=U y$ & & & & 0.001 & $\begin{array}{c}0.1 \\
\text { cementless }\end{array}$ & $\begin{array}{c}10 \\
\text { cemented }\end{array}$ & 1000 \\
\hline
\end{tabular}

\section{Supplementary Information}

The online version contains supplementary material available at https://doi. org/10.1186/s13018-021-02299-4.

Additional file 1. PRISMA 2009 Checklist.

\section{Abbreviations}

TKA: Total knee arthroplasty; DVT: Deep vein thrombosis; ROM: Range of motion; PJI: Periprosthetic joint infection

\section{Acknowledgements}

None

Authors' contributions

The following authors have designed the study (SB), gathered the data ( $L Y$, $L M y)$, analyzed the data ( $Z Y, W Y g)$, wrote the initial drafts $(L Y)$, and ensure the accuracy of the data and analysis (XHq, SB). All authors read and approved the final manuscript.

Funding

None

Availability of data and materials

The datasets used and/or analyzed during the current study are available from the corresponding author on reasonable request.

Ethics approval and consent to participate Not applicable

Consent for publication

Not applicable

Competing interests

The authors declare that they have no competing interests. 


\section{Author details}

'Department of Orthopaedic Surgery, West China Hospital, West China Medical School, Sichuan University, 37\# Guoxue Road, Chengdu 610041, People's Republic of China. ${ }^{2}$ Department of Orthopaedic surgery, National Clinical Research Center for Geriatrics, West China Hospital, Sichuan University, 37\# Guoxue Road, Chengdu 610041, People's Republic of China.

\section{Received: 22 September 2020 Accepted: 10 February 2021}

\section{Published online: 05 March 2021}

\section{References}

1. Matassi F, Carulli C, Civinini R, Innocenti M. Cemented versus cementless fixation in total knee arthroplasty. Joints. 2013;1(3):121.

2. Kim YH, Park JW, Lim HM, Park ES. Cementless and cemented total knee arthroplasty in patients younger than fifty five years. Which is better? Int Orthop. 2014;38(2):297.

3. Chiu FY, Chen CM, Lin CF, Lo WH. Cefuroxime-impregnated cement in primary total knee arthroplasty: a prospective, randomized study of three hundred and forty knees. J Bone Joint Surg Am. 2002;84(5):759.

4. Freeman MA, Tennant $R$. The scientific basis of cement versus cementless fixation. Clin Orthop Relat Res. 1992;276:19.

5. Nugent M, Wyatt MC, Frampton CM, Hooper GJ. Despite improved survivorship of uncemented fixation in total knee arthroplasty for osteoarthritis, cemented fixation remains the gold standard: an analysis of a National Joint Registry. J Arthroplasty. 2019;34(8):1626.

6. Kurtz SM, Lau E, Ong K, Zhao K, Kelly M, Bozic KJ. Future young patient demand for primary and revision joint replacement: national projections from 2010 to 2030. Clin Orthop Relat Res. 2009;467(10):2606.

7. Naudie DD, Ammeen DJ, Engh GA, Rorabeck CH. Wear and osteolysis around total knee arthroplasty. J Am Acad Orthop Surg. 2007;15(1):53

8. Hungerford DS, Krackow KA, Kenna RV. Cementless total knee replacement in patients 50 years old and under. Orthop Clin North Am. 1989;20(2):131.

9. Bassett RW. Results of 1,000 Performance knees: cementless versus cemented fixation. J Arthroplasty. 1998;13(4):409.

10. Alessandro Liberati, Douglas G Altman, Jennifer Tetzlaff, and et al. The PRIS MA statement for reporting systematic reviews and meta-analyses of studies that evaluate healthcare interventions: explanation and elaboration. 2009; 339(undefined): b2700.

11. Hartling L, Ospina M, Liang $Y$, et al. Risk of bias versus quality assessment of randomised controlled trials: cross sectional study. BMJ. 2009;339:b4012.

12. Slim K, Nini E, Forestier D, Kwiatkowski F, Panis Y, Chipponi J. Methodological index for non-randomized studies (minors): development and validation of a new instrument. ANZ J Surg. 2003;73(9):712.

13. Baker PN, Khaw FM, Kirk LM, Esler CN, Gregg PJ. A randomised controlled trial of cemented versus cementless press-fit condylar total knee replacement: 15-year survival analysis. J Bone Joint Surg Br. 2007;89(12): 1608.

14. Carlsson A, Bjorkman A, Besjakov J, Onsten I. Cemented tibial component fixation performs better than cementless fixation: a randomized radiostereometric study comparing porous-coated, hydroxyapatite-coated and cemented tibial components over 5 years. Acta Orthop. 2005;76(3):362.

15. Fernandez-Fairen M, Hernandez-Vaquero D, Murcia A, Torres A, Llopis R. Trabecular metal in total knee arthroplasty associated with higher knee scores: a randomized controlled trial. Clin Orthop Relat Res. 2013:471(11): 3543.

16. Fricka KB, Sritulanondha S, McAsey CJ. To cement or not? Two-year results of a prospective, randomized study comparing cemented vs. cementless total knee arthroplasty (TKA). J Arthroplasty. 2015;30(9 Suppl):55.

17. Fricka KB, McAsey CJ, Sritulanondha S. To cement or not? Five-year results of a prospective, randomized study comparing cemented vs cementless total knee arthroplasty. J Arthroplasty. 2019;34(7S):S183.

18. Gao F, Henricson A, Nilsson KG. Cemented versus uncemented fixation of the femoral component of the NexGen CR total knee replacement in patients younger than 60 years: a prospective randomised controlled RSA study. Knee. 2009;16(3):200

19. Khaw FM, Kirk LM, Morris RW, Gregg PJ. A randomised, controlled trial of cemented versus cementless press-fit condylar total knee replacement. Tenyear survival analysis. J Bone Joint Surg Br. 2002; 84(5): 658

20. McCaskie AW, Deehan DJ, Green TP, Lock KR, Thompson JR, Harper WM, Gregg PJ. Randomised, prospective study comparing cemented and cementless total knee replacement: results of press-fit condylar total knee replacement at five years. J Bone Joint Surg Br. 1998;80(6):971.

21. Nam D, Lawrie CM, Salih R, Nahhas CR, Barrack RL, Nunley RM. Cemented Versus Cementless Total Knee Arthroplasty of the Same Modern Design: A Prospective, Randomized Trial. J Bone Joint Surg Am. 2019;101(13):1185.

22. Park JW, Kim YH. Simultaneous cemented and cementless total knee replacement in the same patients: a prospective comparison of long-term outcomes using an identical design of NexGen prosthesis. J Bone Joint Surg Br. 2011;93(11):1479.

23. Abu-Rajab RB, Watson WS, Walker B, Roberts J, Gallacher SJ, Meek RM. Periprosthetic bone mineral density after total knee arthroplasty. Cemented versus cementless fixation. J Bone Joint Surg Br. 2006;88(5):606

24. Anis HK, Ramanathan D, Sodhi N, Klika AK, Piuzzi NS, Mont MA, Higuera CA, Molloy RM. Postoperative infection in cementless and cemented total knee arthroplasty: a propensity score matched analysis. J Knee Surg. 2019. https:// doi.org/10.1055/s-0039-1678678.

25. Bagsby DT, Issa K, Smith LS, Elmallah RK, Mast LE, Harwin SF, Mont MA, Bhimani SJ, Malkani AL. Cemented vs cementless total knee arthroplasty in morbidly obese patients. J Arthroplasty. 2016;31(8):1727.

26. Boyle KK, Nodzo SR, Ferraro JT, Augenblick DJ, Pavlesen S, Phillips MJ. Uncemented vs cemented cruciate retaining total knee arthroplasty in patients with body mass index greater than 30. J Arthroplasty. 2018;33(4): 1082.

27. Dodd CA, Hungerford DS, Krackow KA. Total knee arthroplasty fixation. Comparison of the early results of paired cemented versus uncemented porous coated anatomic knee prostheses. Clin Orthop Relat Res. 1990; (260): 66

28. Duffy GP, Berry DJ, Rand JA. Cement versus cementless fixation in total knee arthroplasty. Clin Orthop Relat Res. 1998;356:66.

29. Kamath AF, Lee GC, Sheth NP, Nelson CL, Garino JP, Israelite CL. Prospective results of uncemented tantalum monoblock tibia in total knee arthroplasty: minimum 5 -year follow-up in patients younger than 55 years. J Arthroplasty. 2011;26(8):1390.

30. Karachalios T, Komnos G, Amprazis V, Antoniou I, Athanaselis S. A 9-year outcome study comparing cancellous titanium-coated cementless to cemented tibial components of a single knee arthroplasty design. J Arthroplasty. 2018;33(12):3672.

31. Miller AJ, Stimac JD, Smith LS, Feher AW, Yakkanti MR, Malkani AL. Results of Cemented vs Cementless Primary Total Knee Arthroplasty Using the Same Implant Design. J Arthroplasty. 2018;33(4):1089.

32. Pap K, Vasarhelyi G, Gal T, Nemeth G, Abonyi B, Hangody LR, Hangody GM, Hangody L. Evaluation of clinical outcomes of cemented vs uncemented knee prostheses covered with titanium plasma spray and hydroxyapatite: A minimum two years follow-up. Eklem Hastalik Cerrahisi. 2018;29(2):65.

33. Pecina M, Djapic T, Haspl M. Survival of cementless and cemented porouscoated anatomic knee replacements: retrospective cohort study. Croat Med J. 2000:41(2):168

34. Prudhon $\mathrm{L}$, Verdier R. Cemented or cementless total knee arthroplasty? Comparative results of 200 cases at a minimum follow-up of 11 years. SICOT. 2017; J 3: 70

35. Rand JA. Cement or cementless fixation in total knee arthroplasty? Clin Orthop Relat Res. 1991;273:52.

36. Rosenberg AG, Barden RM, Galante JO. Cemented and ingrowth fixation of the Miller-Galante prosthesis. Clinical and roentgenographic comparison after three- to six-year follow-up studies. Clin Orthop Relat Res. 1990;260:71.

37. Sinicrope BJ, Feher AW, Bhimani SJ, Smith LS, Harwin SF, Yakkanti MR, Malkani AL. Increased Survivorship of Cementless versus Cemented TKA in the Morbidly Obese. A Minimum 5-Year Follow-Up. J Arthroplasty. 2019; 34(2):309.

38. Hu B, Chen Y, Zhu H, Wu H, Yan S. Cementless porous tantalum monoblock tibia vs cemented modular tibia in primary total knee arthroplasty: a metaanalysis. J Arthroplasty. 2017;32(2):666.

39. Newman JM, Sodhi N, Dekis JC, Khlopas A, Piuzzi NS, Sultan AA, Levin JM, Mont MA. Survivorship and functional outcomes of cementless versus cemented total knee arthroplasty: a meta-analysis. J Knee Surg. 2020;33(3): 270-8.

40. Gandhi R, Tsvetkov D, Davey JR, Mahomed NN. Survival and clinical function of cemented and uncemented prostheses in total knee replacement: a meta-analysis. J Bone Joint Surg Br. 2009;91(7):889.

41. Zhou K, Yu H, Li J, Wang H, Zhou Z, Pei F. No difference in implant survivorship and clinical outcomes between full-cementless and full- 
cemented fixation in primary total knee arthroplasty: A systematic review and meta-analysis. Int J Surg. 2018;53:312.

42. Chen C, Li R. Cementless versus cemented total knee arthroplasty in young patients: a meta-analysis of randomized controlled trials. J Orthop Surg Res. 2019;14(1):262.

43. Mont MA, Pivec R, Issa K, Kapadia BH, Maheshwari A, Harwin SF. Long-term implant survivorship of cementless total knee arthroplasty: a systematic review of the literature and meta-analysis. J Knee Surg. 2014;27(5):369.

44. Gioe TJ, Killeen KK, Grimm K, Mehle S, Scheltema K. Why are total knee replacements revised?: analysis of early revision in a community knee implant registry. Clin Orthop Relat Res. 2004:428:100.

45. Dalury DF, Pomeroy DL, Gorab RS, Adams MJ. Why are total knee arthroplasties being revised? J Arthroplasty. 2013; 28(null): 120

46. Ritter MA, Meneghini RM. Twenty-year survivorship of cementless anatomic graduated component total knee arthroplasty. J Arthroplasty. 2010;25(4):507.

47. Brown TE, Harper BL, Bjorgul K. Comparison of cemented and uncemented fixation in total knee arthroplasty. Orthopedics. 2013;36(5):380.

48. Lawrie CM, Schwabe M, Pierce A, Nunley RM, Barrack RL. The cost of implanting a cemented cementless total knee arthroplasty. Bone Joint J. 2019;101-B(7_Supple_C):61.

\section{Publisher's Note}

Springer Nature remains neutral with regard to jurisdictional claims in published maps and institutional affiliations.

Ready to submit your research? Choose BMC and benefit from:

- fast, convenient online submission

- thorough peer review by experienced researchers in your field

- rapid publication on acceptance

- support for research data, including large and complex data types

- gold Open Access which fosters wider collaboration and increased citations

- maximum visibility for your research: over $100 \mathrm{M}$ website views per year

At BMC, research is always in progress.

Learn more biomedcentral.com/submissions 